\title{
Correction to: Use of an "Intelligent Knife" (iknife), Based on the Rapid Evaporative lonization Mass Spectrometry Technology, for Authenticity Assessment of Pistachio Samples
}

\author{
Francesca Rigano $^{1} \cdot$ Sara Stead $^{2} \cdot$ Domenica Mangraviti $^{3} \cdot$ Renata Jandova $^{2} \cdot$ Davy Petit $^{4} \cdot$ Nino Marino $^{5}$. \\ Luigi Mondello ${ }^{1,3,6}$ (iD)
}

Published online: 18 December 2018

(C) The Author(s) 2018

\section{Correction to: Food Analytical Methods https://doi.org/10.1007/s12161-018-1386-8}

The article Use of an "Intelligent Knife" (iknife), Based on the Rapid Evaporative Ionization Mass Spectrometry Technology, for Authenticity Assessment of Pistachio Samples, written by Francesca Rigano, Sara Stead, Domenica Mangraviti, Renata Jandova, Davy Petit, Nino Marino and Luigi Mondello, was originally published electronically on the publisher's internet portal (currently SpringerLink) on 19 November 2018 without open access.

With the author(s)' decision to opt for Open Choice the copyright of the article changed on December 2018 to (C) The Author(s) 2018 and the article is forthwith distributed under the terms of the Creative Commons Attribution 4.0

The online version of the original article can be found at https://doi.org/ 10.1007/s12161-018-1386-8

Luigi Mondello

lmondello@unime.it

1 Chromaleont S.r.L c/o Dipatimento di Scienze Chimiche, Biologiche, Farmaceutiche ed Ambientali, Polo Annunziata, University of Messina, Viale Annunziata, 98168 Messina, Italy

2 Waters Corporation, Stamford Avenue, Altrincham Road, Wilmslow SK9 4AX, UK

3 Dipatimento di Scienze Chimiche, Biologiche, Farmaceutiche ed Ambientali, Polo Annunziata, University of Messina, Viale Annunziata, 98168 Messina, Italy

4 Waters Corporation, Waters S.A.S, BP 608 En Yvelines Cedex, 78056 Saint-Quentin, France

5 Pistì - Antichi Sapori dell'Etna S.r.L Viale J.F. Kennedy/Zona artigianale, 12-13 95034, Bronte (CT) Catania, Italy

6 University Campus Bio-Medico of Rome, Via Àlvaro del Portillo 21, 00128 Rome, Italy
International License (http://creativecommons.org/licenses/ by/4.0/), which permits use, duplication, adaptation, distribution and reproduction in any medium or format, as long as you give appropriate credit to the original author(s) and the source, provide a link to the Creative Commons license and indicate if changes were made.

The original article has been corrected.

OpenAccessThis article is distributed under the terms of the Creative Commons Attribution 4.0 International License (http://creativecommons.org/ licenses/by/4.0/), which permits unrestricted use, distribution, and reproduction in any medium, provided you give appropriate credit to the original author(s) and the source, provide a link to the Creative Commons license, and indicate if changes were made.

Publisher's Note Springer Nature remains neutral with regard to jurisdictionalclaims in published maps and institutional affiliations. 